\title{
A Tool to be Used Deliberately: Investigating the Role of Profit in Consumer Co-operatives
}

\author{
Terhi Tuominen ${ }^{1}$, Pasi Tuominen ${ }^{1} \&$ Iiro Jussila ${ }^{1}$ \\ ${ }^{1}$ Department of Management and International Business, School of Business, Lappeenranta University of \\ Technology, Finland \\ Correspondence: Terhi Tuominen, Department of Management and International Business, School of Business, \\ Lappeenranta University of Technology, P.O. Box 20 FIN-58351, Finland. E-mail: terhi.tuominen@lut.fi
}

Received: August 8, 2013

Accepted: September 2, 2013

Online Published: October 28, 2013

doi:10.5539/ibr.v6n11p122

URL: http://dx.doi.org/10.5539/ibr.v6n11p122

\begin{abstract}
Profit is a controversial concept in co-operative literature. It is primarily associated with shareholder corporations and, thereby, sometimes seen as concealing the distinctiveness of the co-operative model. Following our observations from Finnish consumer co-operatives, which highlight the importance of profit, we decided to investigate its role in more detail by thematically analyzing twenty qualitative interviews with $\mathrm{S}$ Group executives and key representatives of governance, asking: why do consumer co-operatives make profit? The findings provide co-operative researchers and practitioners with a more comprehensive understanding on the chain of reasons underlying profit-making in consumer co-operatives. Importantly, the findings also suggest that profit is approached in consumer co-operatives differently than in shareholder corporations and that the difference can be traced back to the set of ideas that make the co-operative a unique model of economic organization.
\end{abstract}

Keywords: consumer co-operation, co-operative, profit, surplus, growth

\section{Introduction}

Shareholder corporations are built on the association of invested capital (Novkovic, 2008; Hansmann, 1996). Their owners are investors, who expect returns on the capital invested (Duska, 1997). They benefit from shareholding in terms of dividends and the increase of share value. Profits are essential for both of these ways of creating value for the owners, which makes investor-owned corporations profit-seeking entities. Profit maximization is placed as a core idea and purpose of the investor-owned model (Jensen \& Meckling, 1976; Friedman, 1970). Further, an essential feature of the public corporation is that shareholders get their share of the firm's market value immediately as their sell their stock. Thereby, the market value of the company is of investors' concern.

Co-operatives are different. It is argued that one of the key distinguishing features of co-operatives as compared to shareholder corporations is that they are built on association of people (the owners) as opposed to capital invested (Jussila, 2012; Novkovic, 2008; Michelsen, 1994). Association of people refers to the fact that the owners compose a community of members, who share mutual interests (e.g., in having particular service needs satisfied) and are also dependent on each other in the pursuit of having those interest served. As it comes to the co-operative organization - a legal (contractual) entity - it can be seen as a tool for the members to serve their mutual interests. Thereby, the member interests serve as the basis of co-operative purpose, which for consumer co-operatives (Tuominen, 2012) is to operate in the consumer market in a manner that creates user-benefits to the consumer-owners (e.g., in terms of lower prices). Further, since the members cannot sell their 'share' of the co-operative (Nilsson, 2001), the members interest in the co-operative is focused on its capacity to provide them with future user-benefits.

Given this purpose, and the fact that they are not investors by their primary role, members do not have a direct interest in profits (Spear, 2004). In fact, consumer-owners may be against profits, since profits (in co-operatives typically referred to as surplus) are made in trade with the owners themselves and, thereby, in their expense (e.g., in terms of higher prices). Consistently, a traditional view of co-operation questioned the role of profit in co-operation (Jokisch, 1994). It was expected that if profit is made due to 'miscalculated prices', it should be 
returned to the members and, according to the principles of co-operation, that should be done in proportion to the members' transactions with the co-operative (Nilsson, 2001; Mills, 2001).

More recent thinking, however, positions profit as an important part of co-operation (Hicks, Maddocks, Robb \& Webb, 2007). Some believe (even if it may not hold for co-operatives) that profit manifests economic efficiency and by showing a level profitability that matches that of their investor-owned peers, co-operatives can prove wrong the general assumption that they are inefficient (Boyle, 2004). More importantly, it is reasoned that a co-operative requires financial resources in order to survive competition (Mills, 2001) and making profit is a convenient way to accumulate those resources (Hicks et al., 2007).

Despite the above discussion, there is scarcity of research focusing on the role of profit in co-operatives. Thereby, profit remains a controversial concept in this context (see e.g., Boyle, 2004; Syrjä, Sjögren \& Tuominen, 2012) and, in our view, one that deserves more research. The process that led to the identification of this gap started with our dealings with Finnish consumer co-operatives and financial media. In the co-operatives, it was often highlighted, consistent with Hicks et al. (2007), that profits are crucial in order invest to the future, to survive. Representatives of financial media on the other hand questioned profits and investments made by consumer co-operatives and called for lower prices, echoing some of the voices we had heard also in the co-operatives. In the view of the journalists, a co-operative making profits and accumulating its own capital reserves is just like any other company-not a unique form following a set of co-operative ideas (for the set of basic ideas of co-operation, see Jussila, 2012; Novkovic, 2008). Following these observations, we decided to study this issue in more detail in order to provide the kind of intellectual framings that can serve to inform both scholarly and practitioner domains. Serving this purpose, we analyze qualitative data (altogether twenty interviews) from Finnish consumer co-operatives asking: (1) why do consumer co-operatives make profit? We go deeper into the chain of reasons that start from profit being a convenient way to accumulate financial resources (Hicks et al., 2007). This is how we push understanding on this issue forward, thereby providing both scientific and practical value.

The paper is structured as follows. Consistent with our research approach, we first provide a detailed account on the context, data and methods of the study. As our research is data-driven, we present our findings first and then discuss their relationship with extant literature. In some areas the literature helps us answer what the data does not and in other areas the data is be used to push co-operative literature forward, in part by bringing in literature from outside the field. Essential is the synthesis that is the outcome of intertwining the data and literature and which provides us with a more detailed understanding on the topic.

\section{Context, Data and Methods}

In more than a hundred years, Finnish retail co-operation has come a long way from small village co-operatives to large scale businesses. Perhaps the most successful example of this is the S Group, which comprises of 20 independent regional co-operatives, eight local co-operatives and the central unit, SOK, which is owned by the co-operatives. S Group has expanded to several fields of business and currently operates in the grocery trade, agricultural trade, consumer goods trade, service station and fuel trade, travel and hotel industry, automotive trade and accessories. In addition, S Group has also established S Bank providing primarily small deposit and loan services (www.s-kanava.net; accessed $14^{\text {th }}$ of May, 2013).

$\mathrm{S}$ Group is currently the market leader of daily consumer goods in Finland with an exceptionally high $45.2 \%$ market share in 2011 (1.1\% increase from the year 2010). At the end of $2012 \mathrm{~S}$ Group had $2.055 \mathrm{million}$ members (at the same time the population of Finland was approximately 5.400 million). Noteworthy, the number of employees in S group has increased rapidly in eight years and at the end of 2012, S Group employed 43417 people (in 2011, approximately 42000 employees). Currently, S Group has over 1600 outlets. (www.s-kanava, accessed $14^{\text {th }}$ of May, 2013).

In 2012, S Group's retail sales were EUR 12 billion (11.46 billion in 2011) and the group's total profit before extraordinary items were 212 million euros (269 million in 2011). In 2012, members were paid 378.5 million in bonuses (360 million in 2011) and the group's investments to new services and new stores / shops were 574 million euros (546 million in 2011) (www.s-kanava.fi; accessed $14^{\text {th }}$ of May, 2013).

\subsection{Data}

Our research process began with some pilot interviews (see Fielding, 1993) with experts of S Group co-operatives. The interviews were carried out by the third author using an instrument developed by an analysis of extensive archive materials on co-operation. The primary purpose of these interviews was to gain understanding on the context of the study and to ascertain the relevance of research questions to the interviewees. 
Two authors continued the process with more interviews on the topic and some related themes. The aim of these tape-recorded thematic interviews (see Braun \& Clarke, 2005) was to deepen our understanding on the strategic management of consumer co-operatives. The authors have also engaged in several informal discussions with the executives of $\mathrm{S}$ Group that have painted a clearer picture of the cases and enabled us to deepen our understanding and test our interpretations.

Altogether, the documented qualitative data (e.g., Denzin \& Lincoln, 1994) analysed for this study consists of twenty interviews. Acknowledging the challenges related to interview data (Eisenhardt \& Graebner, 2007), we engaged into data collection approach that limits bias and chose to interview experts of co-operation, organizational actors from different levels and areas (i.e., CEOs of several regional co-operatives, managers from SOK, and supervisory board chairs of regional co-operatives).

\subsection{Methods}

As the phenomenon we are investigating has not yet received much scholarly attention in this field of research, we believe that our decision to build our research in the form of qualitative thematic analysis is justified (see Gioia, Corley, \& Hamilton, 2012; Braun \& Clarke, 2005). In the interviews, we did not directly ask our research question. Instead, we followed the kind of procedure that has been recently described for example by Gioia et al. (2012), giving the voice to the informants and allowing them to talk about co-operation, co-operative ownership and co-operative management in their own terms.

Following the guidelines of thematic analysis (e.g., Gioia et al., 2012; Braun \& Clarke, 2005), we studied through the data several times, codified it, analyzed it and identified implicit and explicit ideas and associations. The findings were combined to triangulate the themes and then intertwined with the interpretative frameworks (i.e., ideas and associations of ideas in co-operative literature). We first listed all the interview accounts that seemed to speak to our research question (see Braun \& Clarke, 2005). Simplifications of these accounts were defined as $1^{\text {st }}$ order concepts (see Gioia et al., 2012) in our study.

Table 1. Data structure

2nd order themes and the related 1st order concepts

Profit is a safe way to accumulate capital and one that promotes independence

Does not have to show as much profit as the normal capital firm

The slice returned to the owner from annual surplus is smaller than in IOFs and money is allocated to investments

Investment resources must be left to the company

Profitability is the precondition for the existence of operation

Co-operatives need their own resources to be independent

Efficiency of operation cannot be sacrificed

Financial resources are required for competition and regional development

Co-operative has to face the everyday threats of market economy

Critical mass is needed to succeed in competition and to develop

Supermarket trade is a business with so low profit margins that growth is the only way to survival

The surplus goes back to members in the form of investments to the region

Competition and regional development are essential part of executing co-operative purpose in the consumer market and regional economy

The production of economic benefit for the owner in the form of affordable services is the most important goal

Co-operative has to offer better services than a competitor

Ability to operate reliably, predictably and patiently according to the interests of the province and the people

The co-operative is the last one who has to leave the region

Next, we searched for similarities and differences among the $1^{\text {st }}$ order concepts and tried to figure out "is there some deeper structure in this array?" (see Gioia et al., 2012) and moved to axial coding in which we searched 
for relationships between and among categories, which helped to shape the $2^{\text {nd }}$ order themes. Following the work of Gioia et al. (2012), we asked whether the emerging $2^{\text {nd }}$ order themes suggest concepts that might help us describe and explain the phenomenon of interest. At this stage of the research process, we redefined the $2^{\text {nd }}$ order themes several times after re-analyzing the data and intertwining it with extant literature. Table 1 presents the data structure of our study in which we show the $1^{\text {st }}$ order concepts and $2^{\text {nd }}$ order themes. In order to increase the credibility of our interpretations, we also established three separate tables (Tables 2, 3 and 4), in which we present the selected a representative data for each of the $1^{\text {st }}$ order concepts.

In the following, we discuss the findings from our thematic analysis in more detail. Noteworthy, we also discuss our findings in relation to the existing literature on consumer co-operation in those aspects that this literature does not take into consideration or is not well grounded.

\section{Analysis and Synthesis: Intertwining Data and Literature}

As illustrated in Table 1, we established three different 2nd order themes that provide a logical account of the reasoning for profit in consumer co-operatives; 1) Profit is a safe way to accumulate capital and one that promotes independence, 2) Financial resources are required for competition and regional development, and 3) Competition and regional development are essential part of executing the co-operative purpose in the consumer market and regional economy. Next we will provide a more detailed account of the formation of the 2nd order themes by focusing on each of its constitutive 1st order concepts in more detail.

\subsection{Profit is a Safe Way to Accumulate Capital and One that Promotes Independence}

Our data suggests that consumer co-operatives do have to make profit even if they do not have to show it to the extent that investor-owned firms do. That is, they have to make enough profit to be able to secure their future through investments. In that regard, our interviewees highlight that the slice returned to the owner from annual surplus is smaller than in IOFs as investment resources must be left to the company. As put forward by one of the interviewees:

"We cannot operate in the same way than the exchange-listed company... You share maximum amount of profit to shareholders and only the necessity is allocated to investments, we have to operate in a different manner because these investments are the same as this customer-owner, because it develops the (service) network in different regions/areas, as I told you I think it is a brilliant business idea, from many different perspectives.."

This finding provides further understanding on why the co-operatives use their profits to expand their business, as observed by Syrjä et al. (2012). Consistent with extant literature (Hicks et al., 2007), co-operatives use profit as the mechanism to accumulate their own capital resources. This leads us to ask why profit is used as such a mechanism as opposed to relying on, for example, member contributions or outside resources. Our data refers to profit providing the co-operative with independence. This is where extant literature provides us with some answers. It seems that in order to understand the role of profit, we must understand the nature of capital in the co-operative organization.

First, upon the establishment of a co-operative the members build up the initial capital-base by contributing participation shares (Novkovic, 2008; Hicks et al., 2007; Nilsson, 2001; Hansmann, 1996). These shares are typically small in value and can sometimes be partly paid from bonuses that member-candidates receive from patronage with the co-operative (Watkins, 1986). Further, the number of participation shares is not fixed. Instead, the number changes as members join or leave the co-operative. That is, according to the principles of co-operation, the co-operative is open for new members to join, while existing members are free to leave any time they choose to terminate their membership (Novkovic, 2008; Watkins, 1986). The participation shares are individual property of the members, which are paid back to the members when they leave the co-operative (Nilsson, 2001). What this means is that the member contributions can be seen as a loan to the co-operative. This is very different from investor-owned firms in which the capital stock does not decrease when a shareholder sells her/his shares to someone else.

Second, resulting from the nature of shares, the co-operative has "the special financing risk of the co-operative" (Jokisch, 1994, p. 26). As a consequence, it is crucial that a co-operative builds its own capital base and this is done by making profit and retaining it in the co-operative (Hicks, et al., 2007) as collective property of the members (Nilsson, 2001). Thereby, for co-operatives, profit-making is "a means to an end rather than an end in itself" (Cornforth, 2004, p. 15). Considering typical credit policies, making and showing profit could also be seen as important if a co-operative is in need of outside capital (Jokisch, 1994). However, the option of outside liabilities in terms of debt is not encouraged in the co-operative model. Instead, freedom and independence from other organizations (e.g., outside creditors) are amongst the basic ideas of co-operation (Jussila, 2012). This is 
how co-operative principles can be seen as steering co-operatives towards financing their operations by primarily using their profits rather than going outside the co-operative system. Obviously, this is not to say that co-operatives do not use banking services. Following the principle of co-operation amongst co-operatives it is recommended, however, that co-operatives primarily seek for outside capital in another co-operative, such as a co-operative bank (Watkins, 1986).

Highlighting the importance of profit as means to an end (Cornforth, 2004; Davis, 2001), it is put forward in our data that profit-making could be added as a principle for co-operative enterprises. As an interviewee states:

"The task of a co-operative CEO is to take care of the continuity and principles of business meaning that we definitely not have forgotten the principles of business in a co-operative, sometimes we have but not today because the concept of profit is the principle of securing continuity in business"

However, co-operative literature (e.g., Jussila, 2012; Watkins, 1986) indicates that profit is in fact part of co-operative principles even if expressed in different terms. The principle of economy suggests that in co-operation rewards of each operation must exceed its costs. If a co-operative makes losses, in the long run it will cease to exist. According to our data, this principle has not always been remembered in S Group. As a manager commented:

"We forgot these economic factors and all the decisions were made solely by the criteria that could that kind of store bring some joy also and... until we realized that they all were (more or less) unprofitable and the whole good was beginning to disappear... the whole group would fall and at the last moment we had a wake- up call and profitability was given proper attention"

In fact, paying insufficient attention to profitability was one of the major reasons that led S Group to a nearly devastating crisis in 1960s-1980s, during which the group lost its position to its competitors (mainly merchants of Kesko Corporation), who had been efficiently developing their operation. Table 2 provides a summary of the above discussed $1^{\text {st }}$ order concepts; representative supporting data is also included.

Table 2. Profit is a safe way to accumulate capital and one that promotes independence

1st order concepts and the selected representative data
Does not have to show as much profit as the normal capital firm
"Co-operation is, it does not necessarily have to show as much profit as the normal capital firm..."
The slice returned to the owner from annual surplus is smaller than in IOFs and money is allocated to investments
"The return of the surplus and the interests paid to co-operative capital, in kind of, the slice returned to the owner from the annual surplus is
considerable smaller (when compared to IOFs), and if used well, that slice can be used for the development of business...so that in a way...I
see the co-operative perhaps even technically that way that it is a one company form which have significant superiorities or benefits when
compared to other company forms, as long as we are able to use them right."

\section{Investment resources must be left to the company}

"In S group we have even defined it on the paper that what the principles for allocation of the surplus are and in them we have started with the premise thought that the co-operative must be healthy and it must create a certain amount of cash flow financing and cash flow in order it can develop, so investment resources must be left to the company and for the financing and self-fulfilling for these kind of investments and it is until then if there is still something left, then it is returned as interests of co-operative capital or as return of the surplus..."

\section{Co-operatives need their own resources to be independent}

"we looked that we have the preconditions that the co-operative is independent and self-directed so it is able to create itself that kind of resources that it is able to respond to the challenges of the future..."

Profitability is the precondition for the existence of operation

"We have to start from that the precondition for the existence of some kind of operation is that it has to be competitive and profitable, otherwise there is no co-operative and membership and other..."

\section{Efficiency of operation cannot be sacrificed}

\footnotetext{
"In co-operation the meaning of customer feedback is not only in the efficiency of operation but also in directing the services so that they cover the customers' needs as good as possible.. and not necessarily and solely so and the main point is not that does this customer oriented direction of operation produce a better financial result... as long as we keep in mind that we cannot sacrifice the efficiency of operation so that we are not able to produce the services in the long run..."
} 


\subsection{Financial Resources are Required for Competition and Regional Development}

So far, we have established that consumer co-operatives need resources to secure continuity and profit is a convenient way to accumulate them. What remains to be understood in more detail is why existence is in jeopardy without financial resources. The above-mentioned lessons learned by S Group indicate that the answer to this question should not be treated as self-evident. On the other, those lessons also lead us to the answer. That is, our data highlights the fact that consumer co-operatives are market economy actors that face competition. In a competitive environment, any firm pursuing survival and success has to have resources in order to respond to the competitor's moves. As put forward by an interviewee:

"Competition is becoming more intense in daily consumer goods, our main competitor shapes up and probably there will be foreign entrants to Finnish markets too and it means that the price level will fall, it means that we need to accumulate buffers against the fall of the price levels..."

According to our data, critical mass is needed. This is consistent with retailing literature suggesting that retailing organizations are primarily engaged in "the procurement of merchandise for subsequent resale to the end customer" (Robinson \& Clarke-Hill, 1995, p. 179) and in well-functioning retail markets, price is a key competitive element and "the cost of goods sold (i.e., product costs and distribution costs) is the single largest expense item on a retail company's profit and loss account" (Burt \& Sparks, 2003, p. 246). According to our data, critical mass is particularly important in supermarket trade, because it is business with so low profit margins that growth is the only way to survival. In Finland, retail trade (the main branch of S Group) does not grow much and neither does the population of the country (at least not so significantly), mainly people just change places of residence. In the absence of growth, critical mass is likely to become even more important, as "market share exploited through centralized buying processes provides greater scope to negotiate volume and other discounts" (Burt \& Sparks, 2003, p. 246).

Our data also suggests that growth is important, since as more and more people bring their trade to the co-operative (i.e., new members join collective action), also the costs and other trading risks can be spread more widely and prices can be kept low (Mills, 2008). This is yet again one example of why it is important that the surplus made by the co-operative goes back to members in the form of investments to the region. As an interviewee put it:

"..of course this good economic development of the co-operative has assisted us in that we have been able to invest more and we have come back to co-operation and its structure; to us the money has no other pocket to go and the money which has been generated in that good spiral, we have used the cash flow and the bottom line to investments, building up new services and restoring and improving old business units. This has caused a positive spiral in that customers have been happier and we have become more competitive"

Burt and Sparks (2003) refer to this development as a spiral of growth, which begins when increasing scale allied to efficient operation and investment that meets customer demands allows an organization to increase its sales faster than others do. This will then enable cost to fall across the organization and provide further possibilities to invest for operational activities or to reduce price. If the investments to operational activities are successful, they will then continue to attract customers as well as increase sales and market share. In general, such spiral of growth may be critical for consumer co-operatives, since in the capitalistic market economy their competitors are, as Watkins (1986) takes note, typically shareholder corporations that derive their power from capital association.

Our data suggests that competition in the market is not the only reason for the need of resources. It is also the special role of consumer co-operatives as organizations counteracting market failures (Hansmann, 1996). As an interviewee put it:

“...we invest in such places of business, in which no other actor in retail business would even think of building a new unit. We invest to produce services in such municipalities"

For many communities, such a role may be critical. Quite obviously, access to services is likely to be an important factor in people's decision to inhabit a location (cf. Jussila, Kotonen \& Tuominen, 2007). By accumulating resources and assuming the role of a regional developer and promoter of community viability, consumer co-operatives may achieve stability and predictability in their organization-environment relationships. That is, in their classic work in this area, Pfeffer and Salancik (1978) put forward that "growth enhances an organization's survival potential because it provides additional stability and reduces uncertainty and also provides leverage for the organization in managing interorganizational relationships" (p. 139). Because of their size, large organizations have larger constituencies to look after them as well as more important and established relations to business communities. Table 3 provides a summary of the above discussed $1^{\text {st }}$ order concepts; 
representative supporting data is also included.

Table 3. Financial resources are required for competition and regional development

\begin{tabular}{|c|}
\hline 1st order concepts and the selected representative data \\
\hline Co-operative has to face the competition in market economy \\
\hline $\begin{array}{c}\text { "We now that in Finland our main branch, supermarket trade or retail trade does not grow much, population of Finland does not grow, it } \\
\text { just changes the place of residence and due competition price levels have almost deflationary development in supermarket trade and } \\
\text { currently our competitors are probably at a disadvantage in supermarket trade, but we know that K Group does everything in their power to } \\
\text { get everything into shape and possibly also foreign chains will enter so we have threats, but these are everyday threats in a market } \\
\text { economy..." }\end{array}$ \\
\hline Critical mass is needed to succeed in competition and to develop \\
\hline $\begin{array}{l}\text { "we talk about the concept of critical mass, in a way we need to have adequate business and competence in order to be able to develop also } \\
\text { in terms of competence, not only the economic side but also this competence side..." }\end{array}$ \\
\hline Supermarket trade is a business with so low profit margins that growth is the only way to survival \\
\hline $\begin{array}{l}\text { “.especially when talking about supermarket trade the situation is that price competition becomes tougher... the logic of supermarket trade } \\
\text { is that is has no other option than grow, in a way it is a business with so low profit margins that growth is the only way to survival ...” }\end{array}$ \\
\hline The surplus goes back to members in the form of investments to the region \\
\hline $\begin{array}{c}\text { "The surplus that the co-operative generates goes back, we do not have shareholders who get dividends or we do not pay dividend, in our } \\
\text { case the surplus we are able to generate goes back to members, in the form of bonuses and other refunds but also via investments to this } \\
\text { region, for example our co-operative has two ways, we pay more... in every year more than before at least so far and then we invest in this } \\
\text { network, we still have a lot to do with this network...” }\end{array}$ \\
\hline
\end{tabular}

3.3 Competition and Regional Development are Essential Part of Executing Co-operative Purpose in the Consumer Market and Regional Economy

As we start looking into why co-operatives compete and develop their regions, our data suggests that the answer lies in their purpose, which is different as compared to that of shareholder corporations (Tuominen, 2012; Borgen, 2004). As an interviewee put it:

"Maximizing the profit is not the most important task of co-operation; it is bringing about the good services and the development of operation"

Importantly, our interviewees also emphasize the fact that the performance of a consumer co-operative is always relative to other actors in the market (Jussila et al., 2008; Mills, 2001). As put forward by an interviewee:

“..when according to our business idea, we say that the delivering benefits and services to the customer-owner, so in addition to the services, we also have to produce benefits and it is not a benefit if we have the same prices or even higher than the competitors so they have to also have the network close to them, that it is plentiful, I mean all around Finland, it is diverse from car shops to grocery stores"

Co-operatives execute their purpose by providing the goods and services in a more convenient location (Saxena \& Craig, 1999), with higher quality, and/or lower prices (Spear, 2004; Borgen, 2004; Fulton \& Hammond, 1992). The emphasis may vary across market conditions, but the main point is that "a co-operative fulfills its purpose only if it is beneficial to the members relative to alternatives" (Jussila, 2012, p. 3). In other words, consistent with Jussila et al. (2008), our data suggests that in serving its members, a co-operative has to do better than its competitors do in serving them as customers.

Finally, speaking to co-operatives' role as counter actors to failing markets, the purpose of consumer co-operatives is to provide goods and services that are needed, but not provided by other market actors (Jussila et al., 2008). What further stresses the importance regional development is that our interviewees emphasize co-operatives' "ability to operate reliably, predictably and patiently according to the interests of the province and the people". This is consistent with the thoughts of Fairbairn et al. (1991) among others. Co-operatives are expected to be the last to leave their regions and function as vehicles of economic and regional development and promoters of community viability (see e.g., Majee \& Hoyt, 2011; Jussila et al., 2007). While growing co-operatives have more power and leverage over their environment, they are also expected to be responsible and use their power in a way that benefits the entire community (i.e., in accordance with the co-operative 
purpose). Table 4 provides a summary of the above discussed $1^{\text {st }}$ order concepts; representative supporting data is also included.

Table 4. Competition and regional development are essential part of executing co-operative purpose in the consumer market and regional economy

1st order concepts and the selected representative data

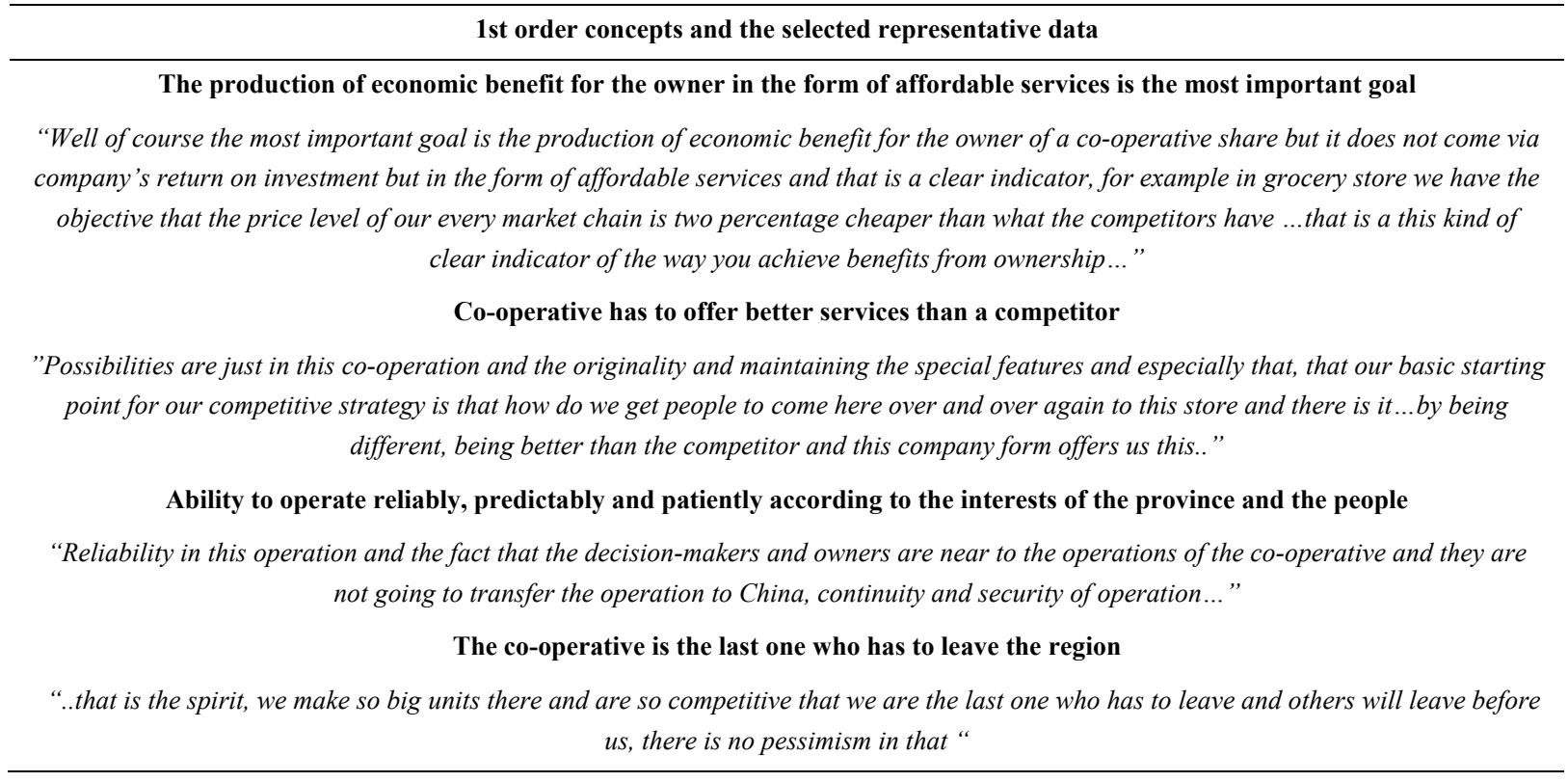

\section{Summary of the Findings}

Consumer co-operatives make profit because it is regarded as a safe way to accumulate capital and one that provides the co-operative with independence. In more detail, co-operatives have to show profit, but not as much as the normal capital firm in which profit is a central goal. In consumer co-operatives profit is used to accumulate resources in order to avoid the risks associated with the nature of capital provided by individual members. That is, the initial capital base is formed from members' small participation shares (which are not fixed in terms of total count) and which are paid back to the members if they leave the co-operative. This causes a specific financial risk in consumer co-operation, and thereby, co-operatives should build their own capital by making profit and retaining it in the co-operative. The idea of profitability can be seen as linked to the principle of economy and, thereby, not a total stranger to the co-operative model.

Co-operatives accumulate these resources since they are required both to respond to competition and to act as regional protectors and developers. Particularly in supermarket trade growth and critical mass is important. By having strong financial resources, consumer co-operatives are able to achieve stability and predictability in their environment which increase their survival potential and reduces the uncertainty stemming from their regional dependence.

Finally, competing and regional development are based on the purpose of co-operatives in the consumer market and regional economy. In more detail, a consumer co-operative fulfils the purpose it was established for only if it is beneficial to members in relation to alternatives (competitors). In an uncompetitive market, a consumer co-operative is supposed to provide goods and services that are needed, but not provided by other market actors. Such a role is important since it is expected from a co-operative that it operates reliably, predictably and patiently according to the interests of the province, which includes securing service provision in the long run: to be the last to leave the community. Figure 1 summarizes the chain of reasoning found through the above-reported iterative process, which answers the question: why do consumer co-operatives make profit?

\section{Discussion and Conclusion}

For consumer co-operatives, profit is a tool that must be used deliberately. Although it is typically associated primarily with a different company form (i.e., the shareholder corporation), it serves a purpose also in consumer co-operatives. The management uses it as it seeks to find a proper balance between the immediate individualistic short-term interests of members and their long term mutual interests. 


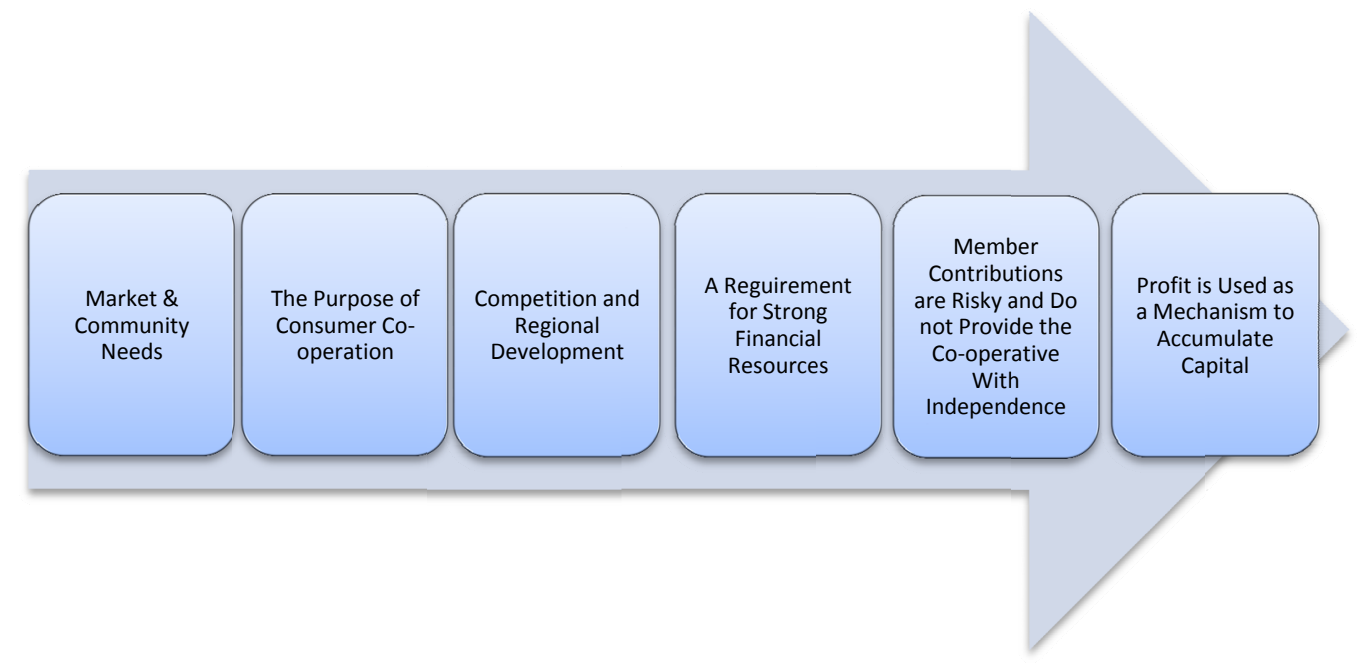

Figure 1. A chain of reasons for profit-making in consumer co-operatives

Prior our study, we already knew that profit is essential for co-operatives in order to accumulate financial resources (Hicks et al., 2007). We also knew that co-operatives use profits to expand their businesses (Syrjä et al., 2012). Our work provides a more holistic view and a more logical understanding on the role of profit in consumer co-operatives. In more detail, now we know why profit is used to accumulate resources instead of member contributions or loans. We also know more broadly why consumer co-operatives accumulate financial resources even if they are not primarily based on capital association. Finally, we now know that this all comes to executing the purpose of co-operatives in the consumer market. In other words, through this study, we now have a chain of reasons that takes us from profit to the purpose of consumer co-operation.

Noteworthy, we have reached this additional understanding by inductively proceeding from data to themes in aniterative process that has made use of extant literature from different co-operative contexts as well as literature from outside the field. Thereby, we not only provide new insight, but also introduce an approach that is new to the discussion on this issue.

The notion that pursuit of risk-avoidance and independence are amongst reasons for using profit to accumulate resources instead of member contributions or loans offers a number of important avenues for future research. For example, it would be useful to study what other means these organizations may utilize to create stability and predictability in their organization-environment-relations. It seems to us that the importance of this question for co-operative management is highlighted due to the geographic-boundness of consumer co-operatives, which stems from their purpose.

The finding that competition and regional development call for financial resources leads us to ask about the role of capital association in consumer co-operatives. How well this is actually addressed in previous research that has highlighted the association of people (the owners) as opposed to capital invested (Jussila, 2012; Novkovic, 2008; Michelsen, 1994) as a key distinctive feature of consumer co-operation. Our work suggests that even though the the social side of co-operation (Novkovic, 2006) is important, it is also important to keep in mind that co-operatives usually operate in the capitalistic market economy (Watkins, 1986), which in many markets requires "big muscles" to survive. It seems to us that this aspect of the co-operative as a tool of the members should not be overlooked. Instead, it deserves more attention and research. Growth is another tricky concept in the context of co-operation. How can co-operatives hold on to their distinct identity (in the competition for social legitimacy), if they are seen as operating like more growth-oriented capitalistic market actor?

Given that competition relates to the execution of the co-operative's purpose in the consumer market, it is worth asking do we know enough about co-operatives as competitive actors? While co-operation and competition may seem like opposite strategies, our work suggests that they co-exist. Consumers co-operate, but their joint co-operative competes with other actors in the market and cannot settle for anything else than victory-at least if it wants to fulfill its purpose. On the other hand, their role as promoters of the market leads us to ask whether their role is - or should be considering the model—collaborative also in their relationships with their competitors. Thereby, more research should be focused on the roles of different kinds of market actors and their reciprocal 
decisions that contribute the evolution of the market and the repositioning of different actors in relation to each other, including the co-operatives.

The high demands that the execution in otherwise demanding conditions or competitive conditions place on consumer co-operatives lead us to ask about the concept of efficiency and the role of efficiency in consumer co-operation. We agree with prior research (e.g., Boyle, 2004) in that we should not assume co-operatives are less efficient than investor-owned firms. However, we also think that we should not be too quick to judge co-operatives as efficient or inefficient simply by comparing their financial results to those of investor-owned firms. We must ask how efficiency is defined and measured across company forms and critically examine to what extent these definitions match and measures are comparable. Further, it would be worth studying what strategies consumer co-operatives use to increase their efficiency as co-operative actors. We certainly hope a lot of research will follow to address this question and other important questions identified through this study.

\section{References}

Borgen, S. O. (2004). Rethinking incentive problems in cooperative organizations. Journal of Socio-Economics, 33, 383-393. http://dx.doi.org/10.1016/S1053-5357(04)00049-6

Boyle, G. E. (2004). The economic efficiency of Irish dairy marketing co-operatives. Agribusiness, 20, 143-153. http://dx.doi.org/10.1002/agr.20000

Braun, V., \& Clarke, V. (2005). Using thematic analysis in psychology. Qualitative Research in Psychology, 3, 77-101. http://dx.doi.org/10.1191/1478088706qp063oa

Burt, S. L., \& Sparks, L. (2003). Power and competition in the UK retail grocery market. British Journal of Management, 14, 237-254. http://dx.doi.org/10.1111/1467-8551.00377

Cornforth, C. (2004). The governance of cooperatives and mutual associations: A paradox perspective. Annals of Public and Cooperative Economics, 75, 11-32. http://dx.doi.org/10.1111/j.1467-8292.2004.00241.x

Davis, P. (2001). The governance of co-operatives under competitive conditions: Issues, processes and culture. Corporate governance, 1, 28-39. http://dx.doi.org/10.1108/EUM0000000005975

Duska, R. F. (1997). The why's of business revisited, Journal of Business Ethics, 16, 1401-1409. http://dx.doi.org/10.1007/978-94-009-1475-9_18

Eisenhardt, K. M., \& Graebner, M. E. (2007). Theory building from cases: opportunities and challenges. Academy of Management Journal, 50, 25-32. http://dx.doi.org/10.5465/AMJ.2007.24160888

Fairbairn, B., Bold, J., Fulton, M., Hammond-Ketilson, L., \& Ish, D. (1991). Co-operatives and community development: economics in social perspective. Centre for the study of co-operatives, University of Saskatchewan.

Fielding, N. (1993). Qualitative Interviewing. In N. Gilbert (Ed.), Researching Social Life (pp. 135-153). London: Sage.

Friedman, M. (1970). The social responsibility of business is to increase its profits. New York Times Magazine, 13 September.

Fulton, M., \& Hammond, K. L. (1992). The role of cooperatives in communities: examples from Saskatchewan. Journal of Agricultural Cooperation, 7, 15-42.

Gioia, D. A., Corley, K. G., \& Hamilton, A. L. (2012). Seeking qualitative rigor in inductive research: notes on the Gioia methodology. Organizational Research Methods. http://dx.doi.org/10.1177/1094428112452151

Hansmann, H. (1996). The Ownership of Enterprise. Cambridge, MA: Belknap Press of Harvard University Press.

Hart, O., \& Moore, J. (1990). Property rights and the nature of the firm. The Journal of Political Economy, 98, 1119-1158. http://dx.doi.org/10.1086/261729

Hicks, E., Maddox, J., Robb, A., \& Webb. T. (2007). Co-operative accountability and identity: an examination of reporting practices of Nova Scotia co-operatives. Journal of Co-operative Studies, 40, 4-16.

Jensen, M., \& Meckling, W. (1976). Theory of the firm: managerial behaviour, agency costs and ownership structure. Journal of Financial Economics, 3, 305-360. http://dx.doi.org/10.1016/0304-405X(76)90026-X

Jokisch, J. (1994). Assesment of success and the distribution of benefits and surplus in co-operatives. In E. Dülfer \& J. Laurinkari (Eds.), International Handbook of Cooperative Organizations (pp. 23-28). Göttingen: Vandenhoeck \& Ruprecht. 
Jussila, I. (2012). Inaugural editorial. Journal of Co-operative Organization and Management. http://dx.doi.org/10.1016/j.jcom.2012.11.001

Jussila, I., Kotonen, U., \& Tuominen, P. (2007). Customer-owned Firms and the Concept of Regional Responsibility: Qualitative Evidence from Finnish Co-operatives. Social Responsibility Journal, 3(3), 35-43. http://dx.doi.org/10.1108/17471110710835563

Jussila, I., Tuominen, P., \& Saksa, J. M. (2008). Following a different mission: where and how do consumer co-operatives compete? Journal of Co-operative Studies, 41, 28-39.

Majee, W., \& Hoyt, A. (2011). Cooperatives and community development: A perspective on the use of cooperatives in development. Journal of Community Practice, 19, 48-61. http://dx.doi.org/10.1080/10705422.2011.550260

Michelsen, J. (1994). The rationales of cooperative organizations. Some suggestions from Scandinavia. Annals of Public and Co-operative Economics, 65, 13-34. http://dx.doi.org/10.1111/j.1467-8292.1994.tb01504.x

Mills, C. (2001). Distributions, and what it means to be a co-operative. Journal of Co-operative Studies, 34(3), $173-181$

Mills, C. (2008). Do large membership-based businesses have a future in the twenty first century? Some reflections on UK retail co-operative societies. Journal of Co-operative Studies, 41, 17-29.

Nilsson, J. (2001). Organisational principles for co-operative firms. Scandinavian Journal of Management, 17, 329-356. http://dx.doi.org/10.1016/S0956-5221(01)00010-0

Norman, K. D., Yvonna, S. L., \& Yvonna, S. L. (1994). Handbook of Qualitative Research. Thousand Oaks, CA: Sage.

Novkovic, S. (2008). Defining the Co-operative Difference. The Journal of Socio-Economics, 37, 2168-2177. http://dx.doi.org/10.1016/j.socec.2008.02.009

Pfeffer, J., \& Salancik, G. R. (1978). The External Control of Organizations: A Resource Dependence Perspective. New York: Harper \& Row.

Robinson, T., \& Clarke-Hill, C. M. (1995). International alliances in European retailing. The International Review of Retail, Distribution and Consumer Research, 5, 167-184. http://dx.doi.org/10.1080/09593969500000012

Saxena, S., \& Craig, J. (1999). Consumer co-operatives in a changing world: A research review. Annals of Public and Cooperative Economics, 61, 489-517. http://dx.doi.org/10.1111/j.1467-8292.1990.tb01358.x

Somerville, P. (2007). Co-operative identity. Journal of Co-operative Studies, 40, 5-17.

Spear, R. (2004). Governance in democratic member-based organisations. Annals of Public and Cooperative Economics, 71, 33-59. http://dx.doi.org/10.1111/j.1467-8292.2004.00242.x

Syrjä, P., Sjögren, H., \& Tuominen, P. (2012). Financial performance and effiency of consumer co-operatives and limited companies-agency theoretical approach. Journal of Co-operative Accounting and Reporting, 1, $143-153$.

Tuominen, P. (2012). The purpose of consumer co-operation: implications for the management and governance of co-operatives. Acta Universitatis Lappeenrantaensis, 487.

Tuominen, P., Jussila, I., \& Kojonen, S. (2009). Overcoming Challenges to Governance of Consumer Co-operation: Analysing Reports of Key Representatives. International Journal of Co-operative Management, 4, 22-35.

Tuominen, P., Jussila, I., \& Rantanen, N. (2010). Managerial competence in consumer co-operatives: inducing theory from empirical observations. International Journal of Co-operative Management, 5, 9-22.

Tuominen, P., Jussila, I., \& Saksa, J. M. (2006). Locality and regionality in management of Finnish customer owned co-operatives. International Journal of Co-operative Management, 3, 9-19.

Watkins, W. P. (1986). Co-operative principle: Today and tomorrow. Manchester: Holyoake Books.

Zeuli, K., \& Radel, J. (2005). Cooperatives as Community Development Strategy: Linking Theory and Practice. The Journal of Regional Analysis \& Policy, 35, 43-54. Retrieved May 14, 2013, from https://www.s-kanava.fi/web/s-kanava-tietoa-s-ryhmasta/en/tietoa-s-ryhmasta

Zeuli, K., Freshwater, D., Markley, D., \& Barkley, D. (2004). Cooperatives in rural community development: a 
new framework for analysis. Journal of the Community Development Society, 35, 17-35. http://dx.doi.org/10.1080/15575330409490130

\section{Copyrights}

Copyright for this article is retained by the author(s), with first publication rights granted to the journal.

This is an open-access article distributed under the terms and conditions of the Creative Commons Attribution license (http://creativecommons.org/licenses/by/3.0/). 